\title{
Prognosis and the Global Impact of the COVID-19 Pandemic - A Comprehensive Review
}

\author{
Syeda Zainab ${ }^{1, *}$, Syed Muhammad Farid Hasan ${ }^{2 *}$, Rabia Noor ${ }^{2}$, Farah Khalid ${ }^{3}$ \\ Monica Parkash J. Ojha \\ 1 Jinnah University for Women Karachi, Pakistan. \\ ¿University of Karachi, Karachi, Pakistan. \\ ${ }^{3}$ Dow University of Health Sciences Karachi, Pakistan.
}

Authors' Contributions

1 Data Analysis and/or Interpretation.

2 Conception \& Study design.

3 Critical Review.

4 Data Collection \& Processing.

5 Drafting of Manuscript.

\begin{abstract}
Acknowledgement
The authors would like to express special thanks to Mr. Muhammad Sikandar, M.Phil. Fellow, Department of Pharmaceutics, Faculty of Pharmacy and Pharmaceutical Sciences, University of Karachi, Pakistan for providing his kind assistance in the preparation of this manuscript.
\end{abstract}

\section{Article info.}

Received: January 28, 2021

Accepted: May 24, 2021

Funding Source: Nil

Conflict of Interest: Nil

Cite this article: Zainab S, Hasan SMF, Noor $R$, Khalid $F$, Ojha MPJ. Prognosis and the Global Impact of the COVID-19 Pandemic - A Comprehensive Review. RADS J Pharm Pharm Sci. 2021; 9(1):66-83.

*Address of Correspondence Author: smfhassan@uok.edu.pk

\begin{abstract}
A B S T R A C T
Background: The novel coronavirus 2019 or SARS-CoV-2 appeared first in the December, 2019, in the Wuhan, China. The virus later effected almost every part of the world.
\end{abstract}

Aim of the Review: The review is aimed to deliver a detailed prognosis of SARS-CoV-2 on basis of evaluation of different attributes of the virus reported or published.

Method: Articles were searched on Google Scholar and PubMed databases. All articles concerning SARS-CoV-2 were included. The duplicate articles were identified with EndNote and excluded. Related data from WHO, FDA and CDC were also included.

Results: The following parameters were found to show an important role in the prognosis of the SARS-CoV-2 i.e., physical properties, evolution, pathogenesis, epidemiology, demography, geography, diagnosis method, laboratory findings and clinical features. Moreover, several approaches were found to fight the viral infection including proposed therapies, proposed drugs, and vaccines. However, till the development of effective and safe approach the preventive measures are recommended to be strictly followed.

Conclusion: The global impact of this virus is beyond reconciliation and rapprochement. Its impact on various major industries such as agriculture, petroleum \& oil, manufacturing industry, education and healthcare, and the pharmaceutical industries is inexplicable.

Keywords: COVID-19, SARS-CoV-2, Pandemic, Evolution, Pathogenesis, Treatment, Vaccine, Economy, Global Impact.

\section{INTRODUCTION}

Severe Acute Respiratory Syndrome Coronavirus 2 (SARS-CoV-2) also known as 2019 novel coronavirus or simply COVID-19 has halted the world at the end of 2019. The first case was reported on $19^{\text {th }}$ December 2019 in Wuhan City, Hubei Province, China. On March 11 $11^{\text {th }}$ 2020, the World Health Organization (WHO) declared it a global pandemic.
There is the uncertainty of the origin however first cases were reported back to Huanan Seafood market where uninhabited animals and specifically bats are sold. [1]. Genetically, SARS-CoV-2 is an RNA enveloped virus. It resembles the Acute Respiratory Syndrome Coronavirus 1 or SARS-CoV-1 and the Middle East Respiratory Syndrome Coronavirus or MERS-CoV [2]. COVID-19 is highly contagious, social 
distancing has decreased the transmission rates and the mortality rates.[1]

SARS-CoV-2 and SARS-CoV-1 have got similarities, and reservoirs were found in camels, however, SARS-CoV was discovered 18 years before the COVID-19 pendamic. [3]. It has been proposed the Bat-CoV acts as a reservoir for the COVID-19 transmit to humans [4]. Characterization and identification of SARS-CoV-2 samples in the laboratory studied a full-length genome sequence of the five patients and revealed $79.6 \%$ and $96 \%$ similarity in gene arrangement with SARS-CoV and bat-virus respectively. The sequence of seven conserved nonstructural proteins has shown its belonging to the SARS-CoV. [5]. SARS-CoV-2 has 10 to 20 folds more binding potential of binding to ACE-2 receptors than the earlier coronaviruses. Its silent and efficient transmission is due to potentially high levels of loads in the nasal secretions of asymptomatic individuals[6].

SARS-CoV-2, SARS-CoV-1, and MERS-CoV have nearly the identical lower respiratory tract related symptoms including shortness of breath and similar chest computed tomography related findings due to SARS-CoV-2 infection [7]. Geriatrics are at more danger of developing severe clinical conditions. The fatality rate of SARS-CoV-2 has been estimated at $3.4 \%$, lower than SARS-CoV-1 and MERS-CoV $(10 \%$ and $34 \%)[8,9]$.

\section{AIM OF THE REVIEW}

The review is aimed to provide a detailed prognosis of SARS-CoV-2 on basis of evaluation of its different attributes reported and published. These attributes such as physical properties, evolution, pathogenesis, epidemiology, demography, geography, diagnosis, and clinical features related to Covid19 are explored in detail.

\section{METHOD}

All articles concerning SARS-CoV-2 were included in this review. The articles were in English language. Articles were searched on google scholar and PubMed using keywords "(SARS-CoV-2 OR coronavirus OR novel coronavirus OR coronavirus 2019) AND (physical properties OR evolution OR pathogenesis OR epidemiology OR demography OR geography OR diagnosis OR laboratory OR findings
OR clinical features OR proposed therapies OR proposed drugs $O R$ vaccines $O R$ preventive measure)" on August 26, 2020. All the articles were included except duplicates. The duplicates were identified using EndNote software. Data from WHO, FDA and CDC were also included.

\section{RESULTS / FINDING}

\section{Physical properties}

SARS-CoV-2 is a Positive-Sense Single-Stranded RNA (+ssRNA) Virus, belongs to the genus Betacoronavirus. Its genome size is almost $27.9 \mathrm{~kb}$ [10]. The genome of SARS-CoV-2 has coding of polyproteins which are large and nonstructural, abbreviated as ORF1a/b, which are further broken down 15-16 proteins, four structural and four accessory proteins [11]. The virus needs structural proteins, the envelope $(\mathrm{E})$ protein, nucleocapsid $(\mathrm{N})$ protein, spike (S) surface glycoprotein, and membrane $(\mathrm{M})$ protein for its assembling and infecting to the hosts. The attachment of the virus with the host's cells is by the help of spike proteins which is further breakdown into S1 and S2 proteins, known as $\mathrm{N}$-terminal $\mathrm{S} 1$ subunit and a membrane-bound $\mathrm{C}$ terminal S2 region [12].

\section{Evolution}

Literature review reveals marked similarity in origin of COVID-19 and SARS-CoV-2 however similar treatments were ineffective to cure COVID-19 infection [13]. Human Transmissible CoVs include epidemics like MERS, SARS-CoV-1 and pandemics like SARS-CoV-2. Bats are primary vector of transmission, majority belonging to the $\alpha-\mathrm{CoV}$ and $\beta$-CoV genera.

$[14,15]$. Phylogenetic studies of RNA-polymerase ( $R d R p$ ) gene of SARS-CoV-2 matches $98.7 \%$ with bat coronavirus strain Bt CoV/4991 and $87.9 \%$ with batSL-CoVZC45 and bat-SL-CoVZXC21 strains. Evolutionary studies confirm SARS-CoV-2 is a new virus [16]. SARS-CoV-2's genomic studies suggested origin is bat or their droppings found in Wuhan seafood market [5].

\section{Pathogenesis}

The spike proteins of the virus attach to ACE-2 receptors in humans, following RNA-based viral genome replication with a unique sequencing for adaption in the human body CoVs genetic mutates by insertion, recombination, deletion, and exchange of 
genes which is the basis for its classification.4 genera and 38 species of CoVs are reported each having different mechanisms of pathogenesis. [14,17,18,19]. The $S$ protein of the virus binds to the ACE-2 receptors (ACE2 acts as the receptor for the SARSCoV-2) resulting in conformational changes in amino acids and salt bridge creation which enhances the Vander Waals interactions [20-22].

SARS-CoV-2 leads to increased expression of ACE-2 hence damaging alveolar tissues. As soon as the virus reaches the host cell, it enters into cytoplasm where it replicates by using transcriptase polyproteins and later is released.[23-25]. The symptoms include, nasal congestion, fatigue, sore throat, myalgia, shortness of breath, fever, dry cough, and conjunctival congestion. Thirty five (35\%) percente to ninty $(90 \%)$ percente of the patients suffer from taste or olfactory dysfunctions. [26-28]. [29, 30]. The rate of Infection is denoted by $R_{0}$. $R_{0}>1$ means, Rate of transmission very high i.e. an epidemic can convert into a pandemic. The $R_{0}$ for SARS-CoV-2 is 3.28 comparatively greater than SARS-CoV-1 [31].

\section{Epidemiology}

The exact origin of virus is unidentified however first infected individual was traced back to seafood market of Wuhan. Initial viral transmission was from animal to human and then it proliferated by humans confirming zoonotic nature. WHO declared SARS-CoV-2 pandemic on $11^{\text {th }}$ March 2020. Individuals infected by virus lied between 25 to 89 years of age while majority was 35 to 55 years old, some infants and children contracted virus too. Median age was determined as 59 years and majority were male patients (59\%). [32]. [33].

Chinese Health Authorities described incubation period of CoV-2 virus is 7 days, extending from two to fourteen days. Symptoms include fever, nonproductive cough, myalgia, shortness of breath, decreased leukocyte counts. Severe cases found to experience severe acute respiratory syndrome, pneumonia , kidney failure and death [34] [35].

\section{Demography}

The onset and progression of COVID-19 can be visualized in Table-1 and 2, indicates the deaths rate has been increasing in different countries. The higher deaths have been reported in America $(305,285$ deaths) and Europe (206,965 deaths), followed by Eastern Mediterranean countries (34,226 deaths), South East Asia (33,543 deaths), Africa $(9,546$ deaths) and Western pacific ( 8005 deaths) by late June, 2020. [36].

Table 1. Worldwide situation of COVID-19 on late June, 2020 [37].

\begin{tabular}{|c|c|c|c|c|c|}
\hline S.No. & Country Name & Total Cases & Active Cases & Deaths & Recovered Cases \\
\hline $\mathbf{1}$ & USA & $2,726,723$ & $1,429,664$ & 130,085 & $1,166,974$ \\
\hline $\mathbf{2}$ & Brazil & $1,408,485$ & 558,789 & 59656 & 790,040 \\
\hline $\mathbf{3}$ & Russia & 647,849 & 225,879 & 9,320 & 412,650 \\
\hline $\mathbf{4}$ & India & 585,792 & 220,546 & 17,410 & 347,836 \\
\hline $\mathbf{5}$ & Spain & 296,351 & 71,038 & 28,355 & 196,958 \\
\hline $\mathbf{6}$ & Peru & 285,213 & 101,001 & 9,677 & 174,535 \\
\hline $\mathbf{7}$ & UK & 282,432 & NA & 43,730 & NA \\
\hline $\mathbf{8}$ & Chile & 279,393 & 32,476 & 5,688 & 241,229 \\
\hline $\mathbf{9}$ & Italy & 240,578 & 15,563 & 34,767 & 190,248 \\
\hline $\mathbf{1 0}$ & Iran & 227,662 & 28,087 & 10,817 & 188,758 \\
\hline $\mathbf{1 1}$ & Mexico & 220,657 & 62,272 & 27,121 & 131,264 \\
\hline $\mathbf{1 2}$ & Pakistan & 209,337 & 106,530 & 4,304 & 98,503 \\
\hline $\mathbf{1 3}$ & Turkey & 199,906 & 21,664 & 5,131 & 173,111 \\
\hline $\mathbf{1 4}$ & Germany & 195,832 & 7,680 & 9,052 & 179,100 \\
\hline $\mathbf{1 5}$ & Saudi Arabia & 190,823 & 58,408 & 1,649 & 130,766 \\
\hline $\mathbf{1 6}$ & France & 164,801 & 58,684 & 29,843 & 76,274 \\
\hline
\end{tabular}




\begin{tabular}{|l|c|c|c|c|c|}
\hline $\mathbf{1 7}$ & South Africa & 151,209 & 75,009 & 2,657 & 73,543 \\
\hline $\mathbf{1 8}$ & Bangladesh & 145,483 & 84,012 & 1,847 & 59,624 \\
\hline $\mathbf{1 9}$ & Canada & 104,204 & 28,019 & 8,591 & 67,594 \\
\hline $\mathbf{2 0}$ & Columbia & 97,846 & 52,439 & 3,334 & 42,073 \\
\hline
\end{tabular}

Table 2. Top 13 countries reported with highest and lowest deaths due to COVID-19 (WHO Health Emergency Dashboard (Data: July 19, 2020) [36].

\begin{tabular}{|c|c|c|c|c|}
\hline S.NO & Country & $\begin{array}{c}\text { Maximum } \\
\text { Cumulative Deaths }\end{array}$ & Country & $\begin{array}{c}\text { Minimum Cumulative } \\
\text { Deaths }\end{array}$ \\
\hline $\mathbf{1}$ & United States of America & 138591 & Brunei Darussalam & 3 \\
\hline $\mathbf{2}$ & Brazil & 78772 & Namibia & 3 \\
\hline $\mathbf{3}$ & Mexico & 38888 & RÃ@union & 3 \\
\hline $\mathbf{4}$ & India & 27497 & Saint Martin & 2 \\
\hline $\mathbf{5}$ & Iran (Islamic Republic of) & 14188 & Belize & 2 \\
\hline $\mathbf{6}$ & Peru & 12998 & $\begin{array}{c}\text { Northern Mariana Islands } \\
\text { (Commonwealth of the) }\end{array}$ & 2 \\
\hline $\mathbf{7}$ & Canada & 8848 & Turks and Caicos Islands & 1 \\
\hline $\mathbf{8}$ & Chile & 8503 & Botswana & 1 \\
\hline $\mathbf{9}$ & Colombia & 6516 & British Virgin Islands & 1 \\
\hline $\mathbf{1 0}$ & Pakistan & 5599 & Burundi & 1 \\
\hline $\mathbf{1 1}$ & Ecuador & 5313 & Cayman Islands & \\
\hline $\mathbf{1 2}$ & South Africa & 5033 & Curacao & 1 \\
\hline $\mathbf{1 3}$ & China & 4653 & Montserrat & \\
\hline
\end{tabular}

Table 3. The top ten countries in this region with a maximum number of cases July 22,2020 [39].

\begin{tabular}{|c|c|c|}
\hline Region & Countries & Maximum Cases \\
\hline \multirow{4}{*}{ Asia } & India & $1,194,085$ \\
\cline { 2 - 3 } & Iran & 278,827 \\
\cline { 2 - 3 } & Pakistan & 278,827 \\
\cline { 2 - 3 } & Saudi Arabia & 255,825 \\
\cline { 2 - 3 } & Turkey & 221,500 \\
\cline { 2 - 3 } & Bangladesh & 210,510 \\
\cline { 2 - 3 } & Qatar & 107,430 \\
\cline { 2 - 3 } & Iraq & 97,159 \\
\cline { 2 - 3 } & Indonesia & 89,869 \\
\hline \multirow{5}{*}{ Europe } & China & 83,693 \\
\cline { 2 - 3 } & Russia & 783,328 \\
\cline { 2 - 3 } & Spain & 783,328 \\
\cline { 2 - 3 } & UK & 295,817 \\
\cline { 2 - 3 } & Italy & 244,752 \\
\cline { 2 - 3 } & Germany & 203,890 \\
\cline { 2 - 3 } & France & 177,338 \\
\cline { 2 - 3 } & Sweden & 78,166 \\
\hline
\end{tabular}




\begin{tabular}{|c|c|c|}
\hline & Belarus & 66,348 \\
\hline & Belgium & 64,094 \\
\hline & Ukraine & 60,166 \\
\hline \multirow{5}{*}{ North America (USA, Canada, Mexico) } & USA & $4,028,569$ \\
\hline & Mexico & 356,255 \\
\hline & Canada & 111,697 \\
\hline & Panama & 55,153 \\
\hline & Haiti & 7,100 \\
\hline \multirow{10}{*}{ South America } & Brazil & $2,166,532$ \\
\hline & Peru & 362,087 \\
\hline & Chile & 334,683 \\
\hline & Colombia & 211,038 \\
\hline & Argentina & 136,118 \\
\hline & Ecuador & 76,217 \\
\hline & Bolivia & 60,991 \\
\hline & Venezuela & 12,774 \\
\hline & French Guiana & 6,851 \\
\hline & Paraguay & 3,817 \\
\hline \multirow{6}{*}{ Australia } & Australia & 12,428 \\
\hline & New Zealand & 1,555 \\
\hline & French Polynesia & 62 \\
\hline & Papua New Guinea & 27 \\
\hline & Fiji & 27 \\
\hline & New Caledonia & 22 \\
\hline
\end{tabular}

\section{Geography}

The pandemic started with the Asian region, Wuhan city, China [38]. Later spread throughout the continent. Later the pandemic developed in Europe, North America, South America region, Africa, Australia Refer Table $\mathbf{3}$ to find The top ten countries region wise [39].

\section{Diagnosis}

The diagnosis of COVID-19 is based on the clinical symptoms, epidemiological history and some supporting clinical testing are like ELISA, Detection of nucleic acid, blood cultures, CT scan, Point of care testing POCT of Immunoglobulins (IgM/lgG), etc.

\section{Technology based on detection of nucleic acid}

Technologies of detection of nucleic acid are used to detect COVID-19, high-throughput sequencing (HTpS) and are real-time quantitative polymerase chain reaction (RT-qPCR). [5]. The HTp-S technology has high cost and dependency on equipment while the,
RT-qPCR offers simplicity, efficacy, and direct method for detection of the virus in blood and secretions of the respiratory tract [40]. It has high specificity and sensitivity against SARS-CoV and MERS-CoV infection [41]. Research showed RTqPCR tests were highly reliable for COVID-19 patients [42]. The sensitivity of the RT-qPCR method is about $50 \%-79 \%$ which depends upon the type of sample and the number of samples which are collected [43]. The rate of detection, biological safety issues by the retained samples and delayed results are some drawbacks of this technique.

\section{CT scan and iagnostic methods}

To avoid the false detection of the virus by RT-qPCR technique, clinicians have proposed CT scans as a supplementary test. The patients are suggested to have repeated tests of RT-qPCR and CT-scan of chest. A High-resolution CT scan is necessary for earlier diagnosis of COVID-19 [44]. The CT scans has drawback of distinguishing between different 
respiratory diseases like other viral pneumonia. It is necessary to develop kits that detect immunologically the presence of antibodies or antigens. [45, 46]. COVID-19 serological test can detect antibodies of SARS-CoV-2in a human body. Antibodies presence indicate that person has been infected and recovered from SARS-CoV-2infection. There are various antibodies test however FDA has not authorized and evaluated all the antibody tests available in the market [47].

To perform antibody test, in-vitro diagnostic (IVD) devices are designed to perform on samples collected from patients such as swab mucus either from inside the nose or back of the throat, or blood collected from a vein or taken from the human body,by pricking finger [48]. The test kit is called the CDC 2019 Novel Coronavirus (2019-nCoV) Real-Time Reverse Transcriptase (RT)-PCR Diagnostic Panel. This was the first laboratory test kit designed in early 2020 by the CDC for the testing of SARS-CoV-2specimens. These kits were then available for consumers. Some laboratories identify an issue with one of the testing reagents while performing validation of the SARSCoV-2test. The problematic reagent was excluded without affecting the accuracy of the test results. This technique was time-saving as it can be used without the addition of a reagent. This was authorized by the FDA and new test kits are available in the market [49].

\section{Clinical features}

COVID-19 patients can be classified into mild, moderate, severe and critical stage. While reported studies show $70 \%$ of patients suffer mild symptoms or remain asymptomatic and $30 \%$ may suffer severe illness [50]. Symptoms in mild stage are dry cough, mild fever, nasal congestion, sore throat, headache, muscle pain, malaise along with vomiting, diarrhea and loss of taste or smell. In moderate stage cough, dyspnea, and tachypnea. In severe stage pneumonia, acute respiratory distress syndrome (ARDS), sepsis, severe dyspnea, tachypnea (respiratory rate $>30$ breath/minute), respiratory distress, $\mathrm{SpO} 2 \leq$ $93 \%, \mathrm{PaO} 2 / \mathrm{FiO} 2<300$, and/or $>50 \%$ lung infiltrates with the virus within 24 to 48 hours. Sometimes in severe cases, fever is not present [51]. In critical stage system or respiratory failure, septic shock, cardiac injury, or multiple organ dysfunction resulting in the death of patients. $5 \%$ patients face this stage [50].

\section{DISCUSSION}

\section{Proposed therapies}

In absence of treatment preventive and supportive measure are adopted to reduce complications. Along with monitoring of vital signs, bed rest and energy intake are encouraged. Antipyretic like acetaminophen and oxygen saturation, Antibiotics such as neuraminidase inhibitors, intravenous fluid resuscitation or vasopressor (norepinephrine for the regulating of persistent shock), Dobutamine (a beta- 1 agonist in management of cardiac shock or severe heart failure) and systemic steroids (hydrocortisone for the reduction of COPD exacerbation) are recommended as supportive therapies [52], [53, 54], [55-57].

NSAIDS especially ibuprofen is prohibited as it could exacerbate the COVID-19 infection instead paracetamol can be used.

[58]. Some Chinese medicines including Shuanghuanglian oral liquid and Lianhua Qingwen capsule are used as supportive therapy. As they can reduce inflammatory responses developed in human body as a result of viruses and bacteria.

$[59,60]$. Early blood purification can reduce renal workload, as ACE-2 receptors are concentrated in kidneys, this process can decrease immune damage as a result of pro-inflammatory and anti-inflammatory factors as well as it maintains electrolytes and acidbase balance [61, 62].

Vitamin $C$ plus vitamin $D$ and vitamin $E$ are also recommended in some studies. These vitamins build resistance towards $\mathrm{nCoV}$

[63].

\section{Proposed drugs}

It is believed that the drugs targeting the SARS-CoV2 main protease ( $\mathrm{M}^{\text {pro }}$ ), an enzyme which is important viral replication and transcription, could play a key role in COVID-19 treatment [64]. The Table 4 shows common therapies investigated for COVID-19 disease but none of these have been approved by Food and Drug Administration (FDA) so far. However, FDA recommended administering COVID-19 convalescent plasma based on the fact that it contains antibodies against SARS-CoV-2on April 8, 2020 [65]. 
Table 4. Proposed therapies against COVID-19 infection.

\begin{tabular}{|c|c|c|c|c|c|}
\hline THERAPIES & DRUG TYPES & $\begin{array}{l}\text { CLINICAL } \\
\text { TRIALS }\end{array}$ & DOSE & FINDINGS & REFERENCES \\
\hline Azithromycin & $\begin{array}{c}\text { Antibacterial } \\
\text { (Macrolide antibiotic) }\end{array}$ & $\begin{array}{c}8 \text { clinical } \\
\text { trials and } \\
6 \text { review } \\
\text { articles }\end{array}$ & $\begin{array}{c}500 \mathrm{mg} \text { day } 1 \text { and } \\
250 \mathrm{mg} \text { days } 2 \text { to } 5 \text {, } \\
500 \mathrm{mg} \text { once daily for } \\
5 \text { days, } 500 \mathrm{mg} \text { orally } \\
\text { in one dose followed } \\
\text { by } 250 \mathrm{mg} \text { in one } \\
\text { dose for a total of } 5 \\
\text { days, } 500 \mathrm{mg} \text { day } 1- \\
3 \text { followed by } 250 \mathrm{mg} \\
\text { day } 4-15\end{array}$ & $\begin{array}{c}3 \text { of the } \\
\text { clinical trials } \\
\text { and } 3 \text { of the } \\
\text { review } \\
\text { articles favor } \\
\text { clinical } \\
\text { benefits of } \\
\text { the drug }\end{array}$ & [66-79] \\
\hline $\begin{array}{c}\text { Chloroquine (CQ) } \\
\text { and } \\
\text { Hydroxychloroquine } \\
\text { (HCQ) }\end{array}$ & Antiprotozoals & $\begin{array}{l}6 \text { clinical } \\
\text { trials and } \\
22 \\
\text { review } \\
\text { articles }\end{array}$ & $\begin{array}{l}600 \mathrm{mg} / \mathrm{d} \text { for } 10 \text { days } \\
\text { (HCQ), } 600 \mathrm{mg} \mathrm{CQ} \\
\text { twice daily for } \\
10 \text { days (CQ) } 450 \mathrm{mg} \\
\text { twice daily on day } 1 \\
\text { and once daily for } 4 \\
\text { days (CQ), } 600 \mathrm{mg} \text { of } \\
\text { hydroxychloroquine } \\
\text { daily (HCQ), } 800 \mathrm{mg} \\
\text { orally in two doses } \\
\text { followed by } 400 \mathrm{mg} \\
\text { daily in two doses for } \\
5 \text { days (HCQ), } 1200 \\
\text { mg daily for three } \\
\text { days followed by a } \\
\text { maintenance dose of } \\
800 \text { mg daily for two } \\
\text { or three weeks } \\
\text { depending upon } \\
\text { severity (HCQ) }\end{array}$ & $\begin{array}{l}2 \text { of the } \\
\text { clinical trials } \\
\text { and } 5 \text { of the } \\
\text { review } \\
\text { articles favor } \\
\text { clinical } \\
\text { benefits of } \\
\text { the drug } \\
\text { while } 2 \text { of } \\
\text { the review } \\
\text { articles } \\
\text { suggest } \\
\text { further } \\
\text { evaluation of } \\
\text { the drugs for } \\
\text { the final } \\
\text { conclusion }\end{array}$ & $\begin{array}{l}{[12,52,66-} \\
72,74,77- \\
\quad 95]\end{array}$ \\
\hline Remdesivir & $\begin{array}{l}\text { Antiviral (Nucleoside } \\
\text { analogue) }\end{array}$ & $\begin{array}{c}2 \text { clinical } \\
\text { trials and } \\
13 \\
\text { review } \\
\text { articles }\end{array}$ & $\begin{array}{l}200 \mathrm{mg} \text { on day } 1 \\
\text { followed by } 100 \mathrm{mg} \\
\text { on days } 2-10 \mathrm{in} \\
\text { single daily infusions } \\
\text { for } 10 \text { days }\end{array}$ & $\begin{array}{l}1 \text { of the } \\
\text { clinical trials } \\
\text { and } 5 \text { of the } \\
\text { review } \\
\text { articles favor } \\
\text { clinical } \\
\text { benefits of } \\
\text { the drug } \\
\text { while } 8 \text { of } \\
\text { the review } \\
\text { articles } \\
\text { suggest } \\
\text { further } \\
\text { evaluation of } \\
\text { the drugs for } \\
\text { the final } \\
\text { conclusion }\end{array}$ & {$[28,96-109]$} \\
\hline
\end{tabular}




\begin{tabular}{|c|c|c|c|c|c|}
\hline Lopinavir/Ritonavir & $\begin{array}{c}\text { Antiviral (Protease } \\
\text { inhibitor) }\end{array}$ & $\begin{array}{l}4 \text { clinical } \\
\text { trials and } \\
5 \text { review } \\
\text { articles }\end{array}$ & $\begin{array}{c}200 / \\
50 \mathrm{mg} \text { P.O.; two } \\
\text { tablets QID for } 5 \\
\text { days, (400 mg and } \\
100 \mathrm{mg}, \\
\text { respectively) twice a } \\
\text { day for } 14 \text { days }\end{array}$ & $\begin{array}{c}3 \text { of the } \\
\text { clinical trials } \\
\text { and } 3 \text { of the } \\
\text { review } \\
\text { articles favor } \\
\text { clinical } \\
\text { benefits of } \\
\text { the drug }\end{array}$ & {$[87,110-117]$} \\
\hline Dexamethasone & $\begin{array}{c}\text { Corticosteroid } \\
\text { (Immunosuppressant) }\end{array}$ & $\begin{array}{l}4 \text { clinical } \\
\text { trials and } \\
2 \text { review } \\
\text { articles }\end{array}$ & $\begin{array}{c}6 \text { mg once daily } \\
\text { (either by } \\
\text { mouth or by } \\
\text { intravenous injection) } \\
\text { for } 10 \text { days }\end{array}$ & $\begin{array}{l}\text { All of the } \\
\text { clinical trials } \\
\text { and review } \\
\text { articles favor } \\
\text { clinical } \\
\text { benefits of } \\
\text { the drug }\end{array}$ & [118-123] \\
\hline $\begin{array}{l}\text { Convalsescent } \\
\text { Plasma }\end{array}$ & Immunomodulator & $\begin{array}{c}5 \text { clinical } \\
\text { trials and } \\
15 \\
\text { review } \\
\text { articles }\end{array}$ & $\begin{array}{c}200-250 \mathrm{~mL} \text { or } \\
\text { based on the clinical } \\
\text { condition of each } \\
\text { patient }\end{array}$ & $\begin{array}{c}3 \text { of the } \\
\text { clinical trials } \\
\text { and } 12 \text { of } \\
\text { the review } \\
\text { articles favor } \\
\text { clinical } \\
\text { benefits of } \\
\text { the drug } \\
\text { while } 1 \text { of } \\
\text { the clinical } \\
\text { trials and } 2 \\
\text { of the review } \\
\text { articles show } \\
\text { uncertainty } \\
\text { or suggest } \\
\text { further } \\
\text { evaluation }\end{array}$ & [124-146] \\
\hline
\end{tabular}

\section{Vaccine}

Among all the isolated proteins of SARS-CoV-2, the key target for COVID-19 vaccine development is the S-protein, based on the evocation of neutralizing antibodies of virus as the immune associates to vaccine defense. The COVID-19 vaccine progress is currently in three different stages. Refer Table 5 [147] [148].

Different types of vaccines are prepared on basis of S-antigen, such as viral vectored vaccines, subunit vaccines, inactivated vaccines, nucleic acid DNA or mRNA-based vaccines. The Partnership for Epidemic Alertness Innovations [149] has provided funding (Table 6). On the contrary, those companies who arenot involved in the drug development and vaccine have simultaneously appeared. It includes US-based companies such as NanoViricides, Novavax, Vir Biotechnology and Johnson \& Johnson,. These companies have declared collective strategies to develop vaccine. Currently, the COVID-19 vaccine is in the Phase-1 clinical trial assessment and will register 45 healthy adult volunteers 18 to 55 years of ages for a period of approximately 6 weeks[149]. 
Table 5. The current status of COVID-19 vaccine development (From: https://www.raps.org/news-andarticles/news-articles/2020).

\begin{tabular}{|c|c|c|}
\hline Investigator & Vaccine applicant & Clinical Trial Stage \\
\hline Moderna & mRNA-1273 & Phase I \\
\hline Casino Biologics & Ad5-nCoV & Phase I \\
\hline Inovio & INO-4800 [150] & Pre-Clinical \\
\hline Pfizer and BioNTech & BNT162(mRNA) & Pre-Clinical \\
\hline Novavax & Recombinant nanoparticle vaccine & Pre-Clinical \\
\hline Curevac & mRNA-based vaccine & Pre-Clinical \\
\hline Generex & Li-key peptide vaccine & Pre-Clinical \\
\hline Vaxart & Oral recombinant vaccine & Research \\
\hline Sanofi & Not revealed & Research \\
\hline Epivax & Li-key peptide vaccine & Research \\
\hline Clover and GSK & S-Trimer & Research \\
\hline iBio & Plant based vaccine & Research \\
\hline MIGAL & Modified avian coronavirus vaccine & Research \\
\hline AJVaccine & Not revealed & Research \\
\hline Codagenix & Live attenuated vaccine & \\
\hline
\end{tabular}

Table 6. Techniques funded by CEPI (From: https://cepi.net/covid-19/).

\begin{tabular}{|c|c|c|}
\hline S.no. & Research organization & Technique \\
\hline $\mathbf{1}$ & Curevac Inc & mRNA \\
\hline $\mathbf{2}$ & Inovio Pharmaceuticals Inc. & DNA \\
\hline $\mathbf{3}$ & Moderna, Inc & Molecular calm \\
\hline $\mathbf{4}$ & University of Queensland & Nanoparticles \\
\hline $\mathbf{5}$ & Novavax & Adenovirus vector \\
\hline $\mathbf{6}$ & University of Oxford & live-attenuated influenza virus \\
\hline $\mathbf{7}$ & University of Hong Kong & measles vector \\
\hline $\mathbf{8}$ & Institute of Pasteur & \\
\hline
\end{tabular}

\section{Vaccine}

Collaborative efforts of the public and government are required for the management and prevention of COVID-19 that is vital to control the spread of diseases. [151].

\section{Outside hospital}

Washing hands with soap, using sanitizer, wearing a mask especially if already coughing and sneezing. Taking precautions in house by using appropriate disinfectant. Avoiding public gatherings and transport.
Reducing interactions with those who are showing symptoms. Closure of offices and educational institutes for some time to flatten the curve. Drink lukewarm water approximately 5 litres/day. Installation of sanitizers in public places[151].

Inside hospital

Overall safety

It is recommended for hospital emergency patients, physicians, and nursing staff. It is advisable to wear a 
disposable/surgical face masks, protective clothing, and gloves [152].

\section{Level 1 safety}

It is applied for outpatient clinics, patients with fever, frontline healthcare workers, and staff in COVID wards. A disposable cap, medical mask (N95 mask is mandatory), and isolation clothing, latex gloves, as well as strict hand hygiene routine [152].

\section{Level 2 safety}

is applied to doctors and nurses working in close contact with confirmed COVID-19 patients and Level 3 safety is applied to aerosol operators for suspected or confirmed patients. Complete protective clothing including cap, goggles, face mask, disposable gloves, shoe covers, and strict adherence to hand sanitization [152].

\section{Global impact}

The impact of COVID-19 chaos on the world economy are summarize primarily focusing some main industries. It includes industries working in the mining of raw materials, production of finished products, education sector and health care industry. Some are discussed below [153].

\section{Impact on Agriculture}

The global demand for agricultural products from restaurants and hotels has dropped by around 20\% [154]. Perishable goods like meat and vegetables are facing less demands as gatherings, travelling and transportation has been banned. Floor trading has stopped for companies like Chicago Mercantile Exchange [155].

\section{Impact on Petroleum \& oil}

Organization of the Petroleum Exporting Countries (OPEC) held meeting in Vienna in march 2020, later that Saudi Arabia reduced oil prices (Reuters, 2020). Hence Saudi oil production rises by $25 \%$ as compared to February 2020. A day sharpest price crash was observed in almost 30 years. On March $23^{\text {rd }}, 2020$ Brent Crude fell by $24 \%$ from $3 \$$ per barrel to stand at $25.70 \$$ per barrel [156].

\section{Impact on the Manufacturing industry}

British Plastics Federation survey [157] revealed impact of COVID-19 on manufacturing businesses in UK, $98 \%$ observed negative impact whereas $80 \%$ predicted decline in turnover for next two quarters [157]. Distancing guidelines has been big concern for businesses as it impacts supply chain, import activities and staffing capability. Work from home option is inadequate for manufacturing industries. Chemical Industry projected $1.2 \%$ reduction in the global production which is lower than the 2008 financial crash (Industry week, 2020).

\section{Impact on Education}

COVID-19 pandemic has impacted schools and universities, leading to completely shut down in some countries like Germany and Italy.

[158] United Kingdom has decided, targeted closure for those who have exposure to any major industry [159]. Moreover, greater than 100 countries closed educational institutes. UNESCO evaluated that 900 million students have been affected [160]. The closures will have extensive socioeconomic consequences (Ali and Alharbi, 2020).

\section{Impact on Healthcare and the Pharmaceutical Industry}

Global health care system witnessed two faced challenge, one maintaining health of patients and doing so protecting healthcare workers too as they are at great risk. Working remotely or implementation of viral testing all carry risk factor [161]. The Pandemic collapsed the health care system as the demand for personal protective equipment's, masks, ventilators and beds skyrocketed, specifically to mention inflated costs. This has led uninsured individuals and frontline workers in USA mentally disturbed [162]. Nicola et al. has emphasized need of change in healthcare dynamics, by faster digitalization and big investment into infectious disease preventive organizations [153]. US import API from EU (26\%), India (18\%) and China (13\%), along with medical equipment from china (39.3\%), this trade has suffered decline [163].

\section{CONCLUSION}

The novel coronavirus 2019 or SARS-CoV-2 was first appeared on the December 2019 in the Wuhan, China. The virus subsequently effected almost every part of the world. Regrettably, no effective and safe treatment has been found against this deadly virus so far. However, several precautionary measures like wearing masks, making social distance, washing hands properly and many more have been exclusively suggested by the organizations including CDC, UNO and FDA for the better prevention of COVID-19 infection. Finally, vaccine is the only cure as suggested by several scientists and clinicians. 
Fortunately, several companies has been developing vaccine against the virus and some have started clinical trials also.

\section{Ethical standards}

No human was involved in the current study. The already published data were reviewed and studied only.

\section{Funding}

This research did not receive any specific grant from funding agencies in the public, commercial, or not-forprofit sectors.

\section{Conflict of interest}

There is no conflict of interest.

\section{REFERENCES}

1. Yang W, Cao Q, Qin LE, Wang X, Cheng Z, Pan A, Dai J, Sun Q, Zhao F, Qu J, Yan F. Clinical characteristics and imaging manifestations of the 2019 novel coronavirus disease (COVID-19): a multi-center study in Wenzhou city, Zhejiang, China. Journal of Infection. 2020; 80(4):388-93.

2. Guan WJ, Ni ZY, Hu Y, Liang WH, Ou CQ, He JX, Liu L, Shan H, Lei CL, Hui DS, Du B. Clinical characteristics of coronavirus disease 2019 in China. New England journal of medicine. 2020; 382(18):1708-20.

3. Sabir JS, Lam TT, Ahmed MM, Li L, Shen Y, AboAba SE, Qureshi MI, Abu-Zeid M, Zhang Y, Khiyami MA, Alharbi NS. Co-circulation of three camel coronavirus species and recombination of MERS-CoVs in Saudi Arabia. Science. 2016; 351(6268):81-4.

4. Lai S, Ruktanonchai NW, Zhou L, Prosper O, Luo W, Floyd JR, Wesolowski A, Santillana M, Zhang C, Du X, Yu H. Effect of non-pharmaceutical interventions to contain COVID-19 in China. nature. 2020; 585(7825):410-3.

5. Zhou $P$, Yang $X L$, Wang XG, Hu B, Zhang L, Zhang W, Si HR, Zhu Y, Li B, Huang CL, Chen HD. A pneumonia outbreak associated with a new coronavirus of probable bat origin. nature. 2020; 579(7798):270-3.

6. Hosoki K, Chakraborty A, Sur S. Molecular mechanisms and epidemiology of COVID-19 from an allergist's perspective. Journal of Allergy and Clinical Immunology. 2020.

7. Huang C, Wang $Y$, Li X, Ren L, Zhao J, Hu Y, Zhang L, Fan G, Xu J, Gu X, Cheng Z. Clinical features of patients infected with 2019 novel coronavirus in Wuhan, China. The lancet. 2020; 395(10223):497-506.
8. Subbaraman N. Why daily death tolls have become unusually important in understanding the coronavirus pandemic. Nature. 2020.

9. Mahase E. Coronavirus: covid-19 has killed more people than SARS and MERS combined, despite lower case fatality rate.

10. Wu F, Zhao S, Yu B, Chen YM, Wang W, Song ZG, Hu Y, Tao ZW, Tian JH, Pei YY, Yuan ML. A new coronavirus associated with human respiratory disease in China. Nature. 2020; 579(7798):265-9.

11. Ramaiah A, Arumugaswami V. Insights into crossspecies evolution of novel human coronavirus 2019-nCoV and defining immune determinants for vaccine development. BioRxiv. 2020.

12. Wrapp D, Wang N, Corbett KS, Goldsmith JA, Hsieh CL, Abiona O, Graham BS, McLellan JS. Cryo-EM structure of the 2019-nCoV spike in the prefusion conformation. Science. 2020; 367(6483):1260-3.

13. Liu Y, Gayle AA, Wilder-Smith A, Rocklöv J. The reproductive number of COVID-19 is higher compared to SARS coronavirus. Journal of travel medicine. 2020

14. Sahin AR, Erdogan A, Agaoglu PM, Dineri $Y$, Cakirci AY, Senel ME, Okyay RA, Tasdogan AM. 2019 novel coronavirus (COVID-19) outbreak: a review of the current literature. EJMO. 2020; 4(1):1-7.

15. Yin Y, Wunderink RG. MERS, SARS and other coronaviruses as causes of pneumonia. Respirology. 2018; 23(2):130-7.

16. Zhu H, Wei L, Niu P. The novel coronavirus outbreak in Wuhan, China. Global health research and policy. 2020; 5(1):1-3.

17. Hikmet ÜN. Coronaviridae virus ailesi: Genel bir değerlendirme. Journal of Advances in VetBio Science and Techniques. 2020; 5(1):1-2.

18. Subissi L, Posthuma CC, Collet A, ZevenhovenDobbe JC, Gorbalenya AE, Decroly E, Snijder EJ, Canard B, Imbert I. One severe acute respiratory syndrome coronavirus protein complex integrates processive RNA polymerase and exonuclease activities. Proceedings of the National Academy of Sciences. 2014; 111(37):E3900-9.

19. Lambeir AM, Durinx C, Scharpé S, De Meester I. Dipeptidyl-peptidase IV from bench to bedside: an update on structural properties, functions, and clinical aspects of the enzyme DPP IV. Critical reviews in clinical laboratory sciences. 2003; 40(3):209-94.

20. Walls AC, Park YJ, Tortorici MA, Wall A, McGuire AT, Veesler D. Structure, function, and antigenicity 
of the SARS-CoV-2 spike glycoprotein. Cell. 2020; 181(2):281-92.

21. Wang Q, Zhang $Y$, Wu L, Niu S, Song C, Zhang Z, Lu G, Qiao C, Hu Y, Yuen KY, Wang Q. Structural and functional basis of SARS-CoV-2 entry by using human ACE2. Cell. 2020; 181(4):894-904.

22. Yan R, Zhang Y, Li Y, Xia L, Guo Y, Zhou Q. Structural basis for the recognition of SARS-CoV-2 by full-length human ACE2. Science. 2020; 367(6485):1444-8.

23. Hussain S, Pan JA, Chen Y, Yang Y, Xu J, Peng Y, Wu Y, Li Z, Zhu Y, Tien P, Guo D. Identification of novel subgenomic RNAs and noncanonical transcription initiation signals of severe acute respiratory syndrome coronavirus. Journal of virology. 2005; 79(9):5288-95.

24. Perrier A, Bonnin A, Desmarets L, Danneels A, Goffard A, Rouillé Y, Dubuisson J, Belouzard S. The C-terminal domain of the MERS coronavirus $M$ protein contains a trans-Golgi network localization signal. Journal of Biological Chemistry. 2019; 294(39):14406-21.

25. Letko M, Marzi A, Munster V. Functional assessment of cell entry and receptor usage for SARS-CoV-2 and other lineage $B$ betacoronaviruses. Nature microbiology. 2020; 5(4):562-9.

26. Lauer SA, Grantz KH, Bi Q, Jones FK, Zheng Q, Meredith HR, Azman AS, Reich NG, Lessler J. The incubation period of coronavirus disease 2019 (COVID-19) from publicly reported confirmed cases: estimation and application. Annals of internal medicine. 2020; 172(9):577-82.

27. Zhou F, Yu T, Du R, Fan G, Liu Y, Liu Z, Xiang J, Wang Y, Song B, Gu X, Guan L. Clinical course and risk factors for mortality of adult inpatients with COVID-19 in Wuhan, China: a retrospective cohort study. The lancet. 2020; 395(10229):1054-62.

28. Chow EJ, Schwartz NG, Tobolowsky FA, Zacks RL, Huntington-Frazier M, Reddy SC, Rao AK. Symptom screening at illness onset of health care personnel with SARS-CoV-2 infection in King County, Washington. Jama. 2020; 323(20):2087-9.

29. Cowart BJ, Flynn-Rodden K, McGeady SJ, Lowry LD. Hyposmia in allergic rhinitis. Journal of allergy and clinical immunology. 1993; 91(3):747-51.

30. Rydzewski B, Pruszewicz A, Sulkowski WJ. Assessment of smell and taste in patients with allergic rhinitis. Acta oto-laryngologica. 2000; 120(2):323-6 .

31. Deerwester J, Gilbertson D. Coronavirus: US says' do not travel'to Wuhan, China, as airlines issue waivers, add safeguards. USA Today. Archived from the original on. 2020.
32. Adhikari SP, Meng S, Wu YJ, Mao YP, Ye RX, Wang QZ, Sun C, Sylvia S, Rozelle S, Raat H, Zhou $H$. Epidemiology, causes, clinical manifestation and diagnosis, prevention and control of coronavirus disease (COVID-19) during the early outbreak period: a scoping review. Infectious diseases of poverty. 2020; 9(1):1-2.

33. Noor AU, Maqbool F, Bhatti ZA, Khan AU. Epidemiology of CoViD-19 Pandemic: Recovery and mortality ratio around the globe. Pakistan journal of medical sciences. 2020; 36(COVID19S4):S79.

34. National Health Commission of People's Republic of China, Prevent guideline of 2019-nCoV. 2020.

35. Rothan HA, Byrareddy SN. The epidemiology and pathogenesis of coronavirus disease (COVID-19) outbreak. Journal of autoimmunity. 2020; 109:102433.

36. WHO, Report, 2020.

37. Worldometer, COVID-19 Coronavirus update. 2020. July 11, 2020.

38. Lai S, Bogoch II, Ruktanonchai NW, Watts A, Lu X, Yang W, Yu H, Khan K, Tatem AJ. Assessing spread risk of Wuhan novel coronavirus within and beyond China, January-April 2020: a travel network-based modelling study. MedRxiv. 2020.

39. virus, W.c., Worldometer corona virus. 2020.

40. Corman VM, Landt O, Kaiser M, Molenkamp R, Meijer A, Chu DK, Bleicker T, Brünink $S$, Schneider J, Schmidt ML, Mulders DG. Detection of 2019 novel coronavirus (2019-nCoV) by realtime RT-PCR. Eurosurveillance. 2020; 25(3):2000045.

41. Woo PC, Lau SK, Wong BH, Tsoi HW, Fung AM, Kao RY, Chan KH, Peiris JM, Yuen KY. Differential sensitivities of severe acute respiratory syndrome (SARS) coronavirus spike polypeptide enzymelinked immunosorbent assay (ELISA) and SARS coronavirus nucleocapsid protein ELISA for serodiagnosis of SARS coronavirus pneumonia. Journal of clinical microbiology. 2005; 43(7):30548.

42. Xie X, Zhong Z, Zhao W, Zheng C. Wang F, Liu J. Chest CT for Typical Coronavirus Disease 2019 (COVID19) Pneumonia: Relationship to Negative RT-PCR Testing. Radiology. 2020; 296(2):41-5.

43. Yam WC, Chan KH, Poon LL, Guan Y, Yuen KY, Seto $W H$, Peiris JS. Evaluation of reverse transcription-PCR assays for rapid diagnosis of severe acute respiratory syndrome associated with a novel coronavirus. Journal of clinical microbiology. 2003; 41(10):4521-4. 
44. Xiong $Y$, Sun D, Liu Y, Fan Y, Zhao L, Li X, Zhu W. Clinical and high-resolution CT features of the COVID-19 infection: comparison of the initial and follow-up changes. Investigative radiology. 2020.

45. Shi $H$, Han $X$, Zheng C. Evolution of CT manifestations in a patient recovered from 2019 novel coronavirus (2019-nCoV) pneumonia in Wuhan, China. Radiology. 2020; 295(1):20.

46. Bernheim A, Mei X, Huang M, Yang Y, Fayad ZA, Zhang N, Diao K, Lin B, Zhu X, Li K, Li S. Chest CT findings in coronavirus disease-19 (COVID-19): relationship to duration of infection. Radiology. 2020; 20:200463.

47. FDA. Antibody (Serology) Testing for COVID-19: Information for Patients and Consumers. 2020; Available from: https://www.fda.gov/medicaldevices/coronavirus-covid-19-and-medicaldevices/antibody-serology-testing-covid-19information-patients-and-consumers.

48. FDA. In Vitro Diagnostics EUAs. 2020; Available from: https://www.fda.gov/medicaldevices/coronavirus-disease-2019-covid-19emergency-use-authorizations-medicaldevices/vitro-diagnostics-euas.

49. CDC. CDC Diagnostic Tests for COVID-19. 2020; Available https://www.cdc.gov/coronavirus/2019ncov/lab/testing.html.

50. Hassan SA, Sheikh FN, Jamal S, Ezeh JK, Akhtar A. Coronavirus (COVID-19): a review of clinical features, diagnosis, and treatment. Cureus. 2020; 12(3).

51. Cascella M, Rajnik M, Aleem A, Dulebohn S, Di Napoli R. Features, evaluation and treatment coronavirus (COVID-19). Statpearls. 2020, StatPearls Publishing.

52. Tang W, Cao Z, Han M, Wang Z, Chen J, Sun W, Wu Y, Xiao W, Liu S, Chen E, Chen W. Hydroxychloroquine in patients with mainly mild to moderate coronavirus disease 2019: open label, randomised controlled trial. bmj. 2020 May 14;369.

53. World Health Organization. Coronavirus (COVID19). 2020. A vailablefrom https://www. who. int/emergencies/diseases/novelcoronavirus2019/events-as-they-happen. 2020.

54. CDC, 2019 Novel Coronavirus (2019-nCoV) Prevention \& Treatment. 2020, March 11.

55. Alhazzani $W$, et al. Surviving Sepsis Campaign: guidelines on the management of critically ill adults with Coronavirus Disease 2019 (COVID-19). Intensive Care Medicine, 2020: 1-34.

56. World Health Organization. Clinical management of severe acute respiratory infection when novel coronavirus ( $\mathrm{nCoV}$ ) infection is suspected: interim guidance, 28 January 2020. World Health Organization; 2020.

57. Mclntosh K, Hirsch MS, Bloom A. Coronavirus disease 2019 (COVID-19). UpToDate Hirsch MS Bloom. 2020 Mar;5(1).

58. Day, M., Covid-19: ibuprofen should not be used for managing symptoms, say doctors and scientists. 2020, British Medical Journal Publishing Group.

59. People's daily of China, The novel coronavirus can be inhibited by Chinese patent medicine Shuanghuanglian oral liquid. 2020.

60. Runfeng L, Yunlong H, Jicheng H, Weiqi P, Qinhai M, Yongxia S, Chufang L, Jin Z, Zhenhua J, Haiming J, Kui Z. Lianhuaqingwen exerts anti-viral and anti-inflammatory activity against novel coronavirus (SARS-CoV-2). Pharmacological research. 2020; 156:104761.

61. Zarbock A, Kellum JA, Schmidt C, Van Aken H, Wempe C, Pavenstädt H, Boanta A, Gerß J, Meersch M. Effect of early vs delayed initiation of renal replacement therapy on mortality in critically ill patients with acute kidney injury: the ELAIN randomized clinical trial. Jama. 2016; 315(20):2190-9.

62. Lim CC, Tan CS, Kaushik M, Tan HK. Initiating acute dialysis at earlier A cute $\mathrm{K}$ idney I njury $\mathrm{N}$ etwork stage in critically ill patients without traditional indications does not improve outcome: A prospective cohort study. Nephrology. 2015; 20(3):148-54.

63. Wang, L.-S., et al. A review of the 2019 Novel Coronavirus (COVID-19) based on current evidence. International Journal of Antimicrobial Agents, 2020: p. 105948.

64. Jin, Z., et al. Structure of Mpro from COVID-19 virus and discovery of its inhibitors. bioRxiv, 2020.

65. U.S. Food and Drug Administration, Recommendations for Investigational COVID-19 Convalescent Plasma. 2020, April 8.

66. Molina JM, Delaugerre C, Le Goff J, Mela-Lima B, Ponscarme D, Goldwirt L, de Castro N. No evidence of rapid antiviral clearance or clinical benefit with the combination of hydroxychloroquine and azithromycin in patients with severe COVID19 infection. Medecine et maladies infectieuses. 2020; 50(4):384.

67. Borba MG, Val FF, Sampaio VS, Alexandre MA, Melo GC, Brito M, Mourão MP, Brito-Sousa JD, Baía-da-Silva D, Guerra MV, Hajjar LA. Effect of high vs low doses of chloroquine diphosphate as adjunctive therapy for patients hospitalized with severe acute respiratory syndrome coronavirus 2 
(SARS-CoV-2) infection: a randomized clinical trial. JAMA network open. 2020 Apr 1;3(4):e208857.

68. Gautret P. et al. Hydroxychloroquine and azithromycin as a treatment of COVID-19: results of an open-label non-randomized clinical trial. International Journal of Antimicrobial Agents, 2020. 56(1): p. 105949.

69. Rosenberg ES, Dufort EM, Udo T, Wilberschied LA, Kumar J, Tesoriero J, Weinberg P, Kirkwood J, Muse A, DeHovitz J, Blog DS. Association of treatment with hydroxychloroquine or azithromycin with in-hospital mortality in patients with COVID-19 in New York State. Jama. 2020 Jun; 323(24):2493502.

70. Mehra MR, et al. Hydroxychloroquine or chloroquine with or without a macrolide for treatment of COVID-19: a multinational registry analysis. The Lancet, 2020.

71. Juurlink DN. Safety considerations with chloroquine, hydroxychloroquine and azithromycin in the management of SARS-CoV-2 infection. Cmaj. 2020; 192(17):E450-3.

72. Damle B, Vourvahis M, Wang E, Leaney J, Corrigan B. Clinical pharmacology perspectives on the antiviral activity of azithromycin and use in COVID-19. Clinical Pharmacology \& Therapeutics. 2020; 108(2):201-11.

73. Ulrich H, Pillat MM. CD147 as a target for COVID19 treatment: suggested effects of azithromycin and stem cell engagement. Stem cell reviews and reports. 2020; 16(3):434-40.

74. Duška $F$, Waldauf $P$, Halačová $M$, Zvoníček $V$, Bala J, Balík M, Beneš J, Klementová $O$, Kozáková I, Kubricht V, Le Roy A. Azithromycin added to hydroxychloroquine for patients admitted to intensive care due to coronavirus disease 2019 (COVID-19)-protocol of randomised controlled trial AZIQUINE-ICU. Trials. 2020; 21(1):1-1.

75. Sivapalan, P., et al. Proactive Prophylaxis With Azithromycin and HydroxyChloroquine in Hospitalised Patients With COVID-19 (ProPACCOVID): A structured summary of a study protocol for a randomised controlled trial. Trials, 2020: 21(1): p. 513-513.

76. Schwartz RA, Suskind RM. Azithromycin and COVID-19: Prompt early use at first signs of this infection in adults and children, an approach worthy of consideration. Dermatologic therapy. 2020;33(4):e13785.

77. Okour, M., M. Al-Kofahi, and D. Austin, Hydroxychloroquine and azithromycin as potential treatments for COVID-19; clinical status impacts the outcome. Journal of pharmacokinetics and pharmacodynamics, 2020; 47(3): p. 187-188.

78. Andreani J, Le Bideau $M$, Duflot I, Jardot $P$, Rolland C, Boxberger M, Wurtz N, Rolain JM, Colson P, La Scola B, Raoult D. In vitro testing of combined hydroxychloroquine and azithromycin on SARS-CoV-2 shows synergistic effect. Microbial pathogenesis. 2020; 145:104228.

79. Abena PM, Decloedt EH, Bottieau E, Suleman F, Adejumo P, Sam-Agudu NA, TamFum JJ, Seydi M, Eholie SP, Mills EJ, Kallay O. Chloroquine and hydroxychloroquine for the prevention or treatment of COVID-19 in Africa: caution for inappropriate off-label use in healthcare settings. The American journal of tropical medicine and hygiene. 2020; 102(6):1184-8.

80. Nicol MR, Joshi A, Rizk ML, Sabato PE, Savic RM, Wesche D, Zheng JH, Cook J. Pharmacokinetics and Pharmacological Properties of Chloroquine and Hydroxychloroquine in the Context of COVID-19 Infection. Clinical Pharmacology \& Therapeutics. 2020; 108(6):1135-49.

81. Sarma P, Kaur H, Kumar H, Mahendru D, Avti P, Bhattacharyya A, Prajapat M, Shekhar N, Kumar $S$, Singh $R$, Singh A. Virological and clinical cure in COVID-19 patients treated with hydroxychloroquine: a systematic review and meta-analysis. Journal of medical virology. 2020; 92(7):776-85.

82. Patel TK, Barvaliya M, Kevadiya BD, Patel PB, Bhalla HL. Does adding of hydroxychloroquine to the standard care provide any benefit in reducing the mortality among COVID-19 patients?: a systematic review. Journal of Neuroimmune Pharmacology. 2020; 15:350-8.

83. Das S, Bhowmick S, Tiwari S, Sen S. An updated systematic review of the therapeutic role of hydroxychloroquine in coronavirus disease-19 (COVID-19). Clinical drug investigation. 2020; 40:591-601.

84. Gies $\mathrm{V}$, Bekaddour N, Dieudonné $\mathrm{Y}$, Guffroy A, Frenger Q, Gros F, Rodero MP, Herbeuval JP, Korganow AS. Beyond anti-viral effects of chloroquine/hydroxychloroquine. Frontiers in immunology. 2020; 11:1409.

85. Khuroo MS, Sofi AA, Khuroo M. Chloroquine and Hydroxychloroquine in Coronavirus Disease 2019 (COVID-19). Facts, Fiction \& the Hype. A Critical Appraisal. International journal of antimicrobial agents. 2020; 106101.

86. Cortegiani A, Ippolito M, Ingoglia G, lozzo P, Giarratano A, Einav S. Update I. A systematic review on the efficacy and safety of 
chloroquine/hydroxychloroquine for COVID-19. Journal of critical care. 2020.

87. Reynard C, Towards evidence-based emergency medicine: best BETs from the Manchester Royal Infirmary. Emergency Medicine Journal, 2020. 37(3): 170.

88. Ren L, Xu W, Overton JL, Yu S, Chiamvimonvat N, Thai PN. Assessment of Hydroxychloroquine and Chloroquine Safety Profiles-A Systematic Review and Meta-Analysis. MedRxiv. 2020.

89. Ibáñez $S$, Martínez $O$, Valenzuela $F$, Silva $F$, Valenzuela $O$. Hydroxychloroquine and chloroquine in COVID-19: should they be used as standard therapy?. Clinical rheumatology. 2020; 39:2461-5.

90. Rodrigo C, Fernando SD, Rajapakse S. Clinical evidence for repurposing chloroquine and hydroxychloroquine as antiviral agents: a systematic review. Clinical Microbiology and Infection. 2020; 26(8):979-87.

91. Oren O, Yang EH, Gluckman TJ, Michos ED, Blumenthal RS, Gersh BJ. Use of chloroquine and hydroxychloroquine in COVID-19 and cardiovascular implications: understanding safety discrepancies to improve interpretation and design of clinical trials. Circulation: Arrhythmia and Electrophysiology. 2020; 13(6):e008688.

92. Singh AK, Singh $A$, Singh $R$, Misra $A$. Hydroxychloroquine in patients with COVID-19: A Systematic Review and meta-analysis. Diabetes \& Metabolic Syndrome: Clinical Research \& Reviews. 2020; 14(4):589-96.

93. Pastick KA, Okafor EC, Wang F, Lofgren SM, Skipper CP, Nicol MR, Pullen MF, Rajasingham R, McDonald EG, Lee TC, Schwartz IS. Hydroxychloroquine and chloroquine for treatment of SARS-CoV-2 (COVID-19). InOpen forum infectious diseases 2020 Apr (Vol. 7, No. 4, p. ofaa130).

94. Chowdhury MS, Rathod J, Gernsheimer J. A rapid systematic review of clinical trials utilizing chloroquine and hydroxychloroquine as a treatment for COVID-19. Academic Emergency Medicine. 2020; 27(6):493-504.

95. Sinha N, Balayla G. Hydroxychloroquine and covid-19. Postgraduate Medical Journal, 2020.

96. Jorgensen SC, Kebriaei R, Dresser LD. Remdesivir: review of pharmacology, pre-clinical data, and emerging clinical experience for COVID-19. Pharmacotherapy: The Journal of Human Pharmacology and Drug Therapy. 2020; 40(7):659-71.

97. Singh AK, Singh A, Singh R, Misra A. Remdesivir in COVID-19: a critical review of pharmacology, pre-clinical and clinical studies. Diabetes \& Metabolic Syndrome: Clinical Research \& Reviews. 2020; 14(4):641-8.

98. Antinori S, Cossu MV, Ridolfo AL, Rech R, Bonazzetti C, Pagani G, Gubertini G, Coen M, Magni C, Castelli A, Borghi B. Compassionate remdesivir treatment of severe Covid-19 pneumonia in intensive care unit (ICU) and NonICU patients: Clinical outcome and differences in post-treatment hospitalisation status. Pharmacological research. 2020; 158:104899.

99. Wang $Y$, Zhang D, Du G, Du R, Zhao J, Jin Y, Fu S, Gao L, Cheng Z, Lu Q, Hu Y. Remdesivir in adults with severe COVID-19: a randomised, double-blind, placebo-controlled, multicentre trial. The lancet. 2020; 395(10236):1569-78.

100. Musa $A$, et al. Remdesivir for the Treatment of COVID-19: A Systematic Review of the Literature. Western Journal of Emergency Medicine: Integrating Emergency Care with Population Health, 2020.

101. Azevedo TC, Azevedo PC, Silveira RN, Carvalho AR, Cezarotti ML, Barbosa FT, Sousa-Rodrigues CF, Matos-Rocha TJ, Ramos FW. Use of remdesivir for patients with Covid-19: a review article. Revista da Associação Médica Brasileira. 2020; 66:838-41.

102. Davis MR, McCreary EK, Pogue JM. That escalated quickly: remdesivir's place in therapy for COVID-19. Infectious diseases and therapy. 2020; 1-12.

103. Sisay M. Available evidence and ongoing clinical trials of remdesivir: could it be a promising therapeutic option for COVID-19?. Frontiers in pharmacology. 2020; 11:791.

104. T Thalha AM, Lee YY, Besari A, Omar SF. Have we found the panacea to COVID-19 with remdesivir, an old but newly packaged drug?. Journal of the Royal College of Physicians of Edinburgh. 2020; 50(2): p. 159-161.

105. Liang C, Tian L, Liu Y, Hui N, Qiao G, Li H, Shi Z, Tang $Y$, Zhang $D$, Xie $X$, Zhao $X$. A promising antiviral candidate drug for the COVID-19 pandemic: A mini-review of remdesivir. European journal of medicinal chemistry. 2020; 201:112527.

106. Pardo J, Shukla AM, Chamarthi G, Gupte A. The journey of remdesivir: from Ebola to COVID-19. Drugs in context. 2020;9.

107. Eastman RT, Roth JS, Brimacombe KR, Simeonov A, Shen M, Patnaik S, Hall MD. Remdesivir: a review of its discovery and development leading to emergency use authorization for treatment of COVID-19. ACS central Science. 2020; 6(5):67283. 
108. Davies M, Osborne V, Lane S, Roy D, Dhanda S, Evans A, Shakir S. Remdesivir in treatment of COVID-19: a systematic benefit-risk assessment. Drug safety. 2020; p. 1.

109. Cao YC, Deng QX, Dai SX. Remdesivir for severe acute respiratory syndrome coronavirus 2 causing COVID-19: An evaluation of the evidence. Travel medicine and infectious disease. 2020; 35:101647.

110. Dastan F, Nadji SA, Saffaei A, Marjani M, Moniri A, Jamaati $H$, Hashemian SM, Baghaei P, Abedini A, Varahram M, Yousefian S. Subcutaneous administration of interferon beta-1a for COVID-19: A non-controlled prospective trial. International immunopharmacology. 2020; 85:106688.

111. Hung IF, Lung KC, Tso EY, Liu R, Chung TW, Chu MY, Ng YY, Lo J, Chan J, Tam AR, Shum HP. Triple combination of interferon beta-1b, lopinavirritonavir, and ribavirin in the treatment of patients admitted to hospital with COVID-19: an open-label, randomised, phase 2 trial. The Lancet. 2020; 395(10238):1695-704.

112. Cao B, Wang $Y$, Wen D, Liu W, Wang J, Fan G, Ruan L, Song B, Cai Y, Wei M, Li X. A trial of lopinavir-ritonavir in adults hospitalized with severe Covid-19. New England Journal of Medicine. 2020.

113. Chu CM, Cheng VC, Hung IF, Wong MM, Chan $\mathrm{KH}$, Chan KS, Kao RY, Poon LL, Wong CL, Guan $Y$, Peiris JS. Role of lopinavir/ritonavir in the treatment of SARS: initial virological and clinical findings. Thorax. 2004; 59(3):252-6.

114. Drożdżal S, Rosik J, Lechowicz K, Machaj F, Kotfis K, Ghavami S, Łos MJ. FDA approved drugs with pharmacotherapeutic potential for SARS-CoV2 (COVID-19) therapy. Drug resistance updates. 2020;100719.

115. Codispoti CD, Bandi S, Patel P, Mahdavinia M. Clinical course of asthma in 4 cases of coronavirus disease 2019 infection. Annals of Allergy, Asthma \& Immunology. 2020; 125(2):208-10.

116. Meini S, Pagotto A, Longo B, Vendramin I, Pecori D, Tascini C. Role of Lopinavir/Ritonavir in the treatment of Covid-19: a review of current evidence, guideline recommendations, and perspectives. Journal of clinical medicine. 2020; 9(7):2050.

117. Yao TT, Qian JD, Zhu WY, Wang Y, Wang GQ. A systematic review of lopinavir therapy for SARS coronavirus and MERS coronavirus-A possible reference for coronavirus disease-19 treatment option. Journal of medical virology. 2020; 92(6):556-63.

118. Solinas C, Perra L, Aiello M, Migliori E, Petrosillo N. A critical evaluation of glucocorticoids in the management of severe COVID-19. Cytokine \& growth factor reviews. 2020.

119. Rizk JG, Kalantar-Zadeh K, Mehra MR, Lavie CJ, Rizk Y, Forthal DN. Pharmaco-immunomodulatory therapy in COVID-19. Drugs. 2020;1-26.

120. Johnson RM, Vinetz JM. Dexamethasone in the management of covid -19. Bmj, 2020; 370: 2648.

121. Ledford $\mathrm{H}$. Coronavirus breakthrough: dexamethasone is first drug shown to save lives. Nature, 2020; 582(7813): 469.

122. Ruch Y. Rapid Radiological Worsening and Cytokine Storm Syndrome in COVID-19 Pneumonia. Eur J Case Rep Intern Med, 2020; 7(7): 001822.

123. Kupferschmidt, K., U.K. megatrial outshines other drug studies. Science, 2020. 369(6500): p. 124125.

124. Olivares-Gazca JC, et al. Infusion of convalescent plasma is associated with clinical improvement in critically ill patients with covid-19: a pilot study. Rev Invest Clin, 2020. 72: 159-164.

125. Erkurt MA, Sarici A, Berber I, Kuku I, Kaya E, Özgül M. Life-saving effect of convalescent plasma treatment in covid-19 disease: clinical trial from eastern Anatolia. Transfusion and Apheresis Science. 2020; 59(5):102867.

126. Li L, Zhang $\mathrm{W}$, Hu Y, Tong $X$, Zheng S, Yang J, Kong $Y$, Ren L, Wei Q, Mei H, Hu C. Effect of convalescent plasma therapy on time to clinical improvement in patients with severe and lifethreatening COVID-19: a randomized clinical trial. Jama. 2020; 324(5):460-70.

127. Abolghasemi $H$, Eshghi $P$, Cheraghali AM, Fooladi AA, Moghaddam FB, Imanizadeh S, Maleki MM, Ranjkesh M, Rezapour M, Bahramifar A, Einollahi B. Clinical efficacy of convalescent plasma for treatment of COVID-19 infections: Results of a multicenter clinical study. Transfusion and Apheresis Science. 2020 Oct 1;59(5):102875.

128. Shankar-Hari $M$, et al. Convalescent plasma to treat critically ill patients with COVID-19: framing the need for randomised clinical trials. Critical care (London, England), 2020. 24(1): 449-449.

129. Eckhardt CM, Cummings MJ, Rajagopalan KN, Borden S, Bitan ZC, Wolf A, Kantor A, Briese T, Meyer BJ, Jacobson SD, Scotto D. Evaluating the efficacy and safety of human anti-SARS-CoV-2 convalescent plasma in severely ill adults with COVID-19: A structured summary of a study protocol for a randomized controlled trial. Trials. 2020 Dec; 21(1):1-3. 21(1): p. 499.

130. Perotti C, Del Fante C, Baldanti F, Franchini M, Percivalle E, Vecchio Nepita E, Seminari E, De 
Silvestri A, Bruno R, Klersy C. Plasma from donors recovered from the new Coronavirus 2019 as therapy for critical patients with COVID-19 (COVID-19 plasma study): a multicentre study protocol. Internal and emergency medicine. 2020; 15:819-24.

131. Murphy M, Estcourt L, Grant-Casey J, Dzik S. International survey of trials of convalescent plasma to treat COVID-19 infection. Transfusion medicine reviews. 2020; 34(3):151-7.

132. Psaltopoulou T, Sergentanis TN, Pappa V, Politou M, Terpos E, Tsiodras S, Pavlakis GN, Dimopoulos MA. The emerging role of convalescent plasma in the treatment of COVID19. Hemasphere. 2020; 4(3): p. e409.

133. Piechotta V, et al. Convalescent plasma or hyperimmune immunoglobulin for people with COVID-19: a living systematic review. Cochrane Database of Systematic Reviews. 2020;(7).

134. Yiğenoğlu TN, et al. Convalescent plasma therapy in patients with COVID-19. Journal of Clinical Apheresis, 2020.

135. Annamaria $P$, Eugenia $Q$, Paolo S. Anti-SARSCoV-2 hyperimmune plasma workflow. Transfusion and Apheresis Science. 2020; 59(5):102850..

136. Accorsi $P$, Berti $P$, De Angelis V, De Silvestro G, Mascaretti L, Ostuni A. Position paper on the preparation of immune plasma to be used in the treatment of patients with COVID-19. Transfusion and Apheresis Science. 2020; 59(4):102817.

137. Seghatchian J, Lanza F. Convalescent plasma, an apheresis research project targeting and motivating the fully recovered COVID 19 patients: a rousing message of clinical benefit to both donors and recipients alike. Transfusion and Apheresis Science. 2020; 59(3):102794.

138. evasenapathy $\mathrm{N}, \mathrm{Ye} Z$, Loeb $M$, Fang $F$, Najafabadi BT, Xiao Y, Couban R, Bégin P, Guyatt G. Efficacy and safety of convalescent plasma for severe COVID-19 based on evidence in other severe respiratory viral infections: a systematic review and meta-analysis. Cmaj. 2020.

139. Pawar AY, Hiray AP, Sonawane DD, Bhambar RS, Derle DV, Ahire YS. Convalescent plasma: a possible treatment protocol for COVID-19 patients suffering from diabetes or underlying liver diseases. Diabetes \& Metabolic Syndrome: Clinical Research \& Reviews. 2020.

140. Valk SJ, Piechotta V, Chai KL, Doree C, Monsef I, Wood EM, Lamikanra A, Kimber C, McQuilten Z, So-Osman C, Estcourt LJ. Convalescent plasma or hyperimmune immunoglobulin for people with
COVID-19: a rapid review. Cochrane Database of Systematic Reviews. 2020(5).

141. Rojas M, Rodríguez Y, Monsalve DM, AcostaAmpudia Y, Camacho B, Gallo JE, RojasVillarraga A, Ramírez-Santana C, Díaz-Coronado JC, Manrique R, Mantilla RD. Convalescent plasma in Covid-19: Possible mechanisms of action. Autoimmunity reviews. 2020; 19(7):102554.

142. Barone $\mathrm{P}, \mathrm{DeSimone} R A$. Convalescent plasma to treat coronavirus disease 2019 (COVID-19): considerations for clinical trial design. Transfusion. 2020.

143. Sullivan HC, Roback JD. Convalescent plasma: therapeutic hope or hopeless strategy in the SARS-CoV-2 pandemic. Transfusion medicine reviews. 2020.

144. Cao H, Shi Y. Convalescent plasma: possible therapy for novel coronavirus disease 2019. Transfusion. 2020 May;60(5):1078.

145. Brown BL, McCullough J. Treatment for emerging viruses: Convalescent plasma and COVID-19. Transfusion and Apheresis Science. 2020 Jun 1;59(3):102790.

146. Tiberghien $P$, de Lamballerie $X$, Morel $P$, Gallian $\mathrm{P}$, Lacombe K, Yazdanpanah Y. Collecting and evaluating convalescent plasma for COVID-19 treatment: why and how?. Vox sanguinis. 2020; 115(6):488-94.

147. Yii AC, Tay TR, Choo XN, Koh MS, Tee AK, Wang DY. Precision medicine in united airways disease: a "treatable traits" approach. Allergy. 2018; 73(10):1964-78.

148. Jeff C. COVID-19 vaccine tracker. 2020; Available from:https://www.raps.org/news-and-articles/newsarticles/2020/3/covid-19-vaccine-tracker.

149. CEPI. 2020; Available from: https://cepi.net/covid$19 /$.

150. Meo SA, Al-Khlaiwi $T$, Usmani AM, Meo AS, Klonoff DC, Hoang TD. Biological and epidemiological trends in the prevalence and mortality due to outbreaks of novel coronavirus COVID-19. Journal of King Saud UniversityScience. 2020.

151. Ali I, Alharbi OM. COVID-19: Disease, management, treatment, and social impact. Science of the total Environment. 2020; 728:138861.

152. eng $M$. The prevention and management of the coronavirus disease 2019 (COVID-19) outbreak in radiology departments in epidemic areas. Japanese journal of radiology. 2020.

153. Nicola M, Alsafi Z, Sohrabi C, Kerwan A, Al-Jabir A, losifidis C, Agha M, Agha R. The socio- 
economic implications of the coronavirus pandemic (COVID-19): A review. International journal of surgery. 2020; 78:185-93.

154. Rediff. Prices of agricultural commodities drop $20 \%$ post COVID-19 outbreak - rediff Realtime 2020.

Marek L. CME closing trading floors indefinitely amid coronavirus concerns. Chicago Business, 2020.

155. 2020; Available from: https://www.npr.org/2020/03/08/813439501/saudiarabia-stuns-world-with-massive-discount-in-oilsold-to-asia-europe-and-u-.

156. BPF. Plastics Trade Body Publishes First Study of Coronavirus Impact on UK Manufacturing. 2020; Available from: https://www.bpf.co.uk/article/plastics-trade-bodypublishes-first-study-of-coronavirus-impact1602.aspx.

157. Km. 2020; Available from: https://www.km.bayern.de/.

158. GOV.UK. Guidance for schools: coronavirus (COVID-19). 2020; Available from: https://www.gov.uk/government/collections/guidan ce-for-schools-coronavirus-covid-19.

159. UNESCO. COVID-19 Educational Disruption and Response. 2020; Available from: https://en.unesco.org/news/covid-19-educationaldisruption-and-response.

160. Tanne JH, Hayasaki E, Zastrow M, Pulla P, Smith P, Rada AG. Covid-19: how doctors and healthcare systems are tackling coronavirus worldwide. Bmj. 2020; 368.

161. KFF. What Issues Will Uninsured People Face with Testing and Treatment for COVID-19? 2020; Available from: https://www.kff.org/coronaviruscovid-19/fact-sheet/what-issues-will-uninsuredpeople-face-with-testing-and-treatment-for-covid$19 /$.

162. Vara V. Coronavirus in the US: COVID-19 outbreak, measures and impact. 2020; Available from: https://www.pharmaceuticaltechnology.com/features/coronavirus-affectedcountries-usa-covid-19-measures-impact-pharmahotel-tourism-medical/.

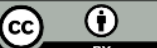

This is an Open Access article distributed under the terms of the Creative Commons Attribution License (http://creativecommons.org/licenses/by/4.0), which permits unrestricted use, distribution, and reproduction in any medium, provided the original work is properly cited. 